\title{
Jewish Attitudes to the Reconstruction of Synagogues in post World War II Europe
}

\author{
Michael Turner
}

\begin{abstract}
Kristallnacht, 1938, was a defining moment, changing the course of history. Can the Jewish heritage destroyed before and during World War II be reconstructed? This paper will link eschatological thought and the relevant Mishnaic texts, in particular the value of holiness and its attributes both in time and place. Can a synagogue be de-sanctified? Is the value in the material or the use?

Reviewing these tragic events, the possible criteria for reconstructing the architectural components of Jewish life should be considered, through the evidence of history, the record of events, values of the past, and the new realities of the future. Another significant concern is not so much in understanding the changing and diverse values of a community but the approaches toward the interpretations of these values. In this debate, where existential or historical models play a major role, Judaism tends toward the former, recalling events over time and the allegory in the facts.

What remained in Europe were the ruins, the memory of places and events, and the resilience of the human spirit. However, there are compounded memories and multiple voices, ever changing, challenging the identities of real and virtual communities. How do we evaluate the facts and the extended contexts over time that demand renegotiation of their meaning and interpretation?

On current projections, the Jews may become an insignificant number in European society over the course of the twenty-first century. Can these buildings, as reconstructed, live without the spirit of the people; can new people inhabit the reconstructions, or is the ruin the true manifestation of the course of history? The divergent case studies of the three ShUM cities, Speyer, Worms, and Mainz, in Germany provide a glimpse into the debate and an appraisal of the moment in time.
\end{abstract}

Published jointly by the United Nations Educational, Scientific and Cultural Organization (UNESCO), 7, place de Fontenoy, 75007 Paris, France, the UNESCO Office in Kabul, ICON Compound, Supreme Road, Off Jalalabad Road, PD 9, Kabul, Afghanistan, and Springer Nature Switzerland AG, Gewerbestrasse 1, 6330 Cham, Switzerland.

M. Turner $(\bowtie)$

UNESCO Chair in Urban Design and Conservation Studies, Bezalel Academy of Arts

and Design, Jerusalem, Israel

e-mail: unescochair@bezalel.ac.il 
There are common attitudes facing recovery and reconstructions for uprooted communities after tragedies that leave scars on history. The case studies of Jewish heritage reconstruction and the considerations of impermanence provide another perspective to the restorations of the Bamiyan Buddhas and together a chilling evidence to the consequences of racism.

Keywords Jewish heritage $\cdot$ Memory $\cdot$ Synagogues $\cdot$ Reconstruction $\cdot$ ShUM cities $\cdot$ Values $\cdot$ Sanctity $\cdot$ Attributes

\section{Background}

The two world wars of the twentieth century left Europe shattered and millions killed. Kristallnacht - or the Night of Broken Glass - on November 9, 1938, from Vienna to Worms, was a pogrom that represented the crescendo of centuries of antiSemitism when Jewish homes, hospitals, and schools were razed, with over 1000 synagogues burned and more than 7000 Jewish businesses either destroyed or damaged, subsequently deteriorating into the systematic murdering of Jews and the destruction of Jewish heritage. As Martin Gilbert stated at the time (Gilbert 2006), no other event in the history of German Jews between 1933 and 1945 was so widely reported as it was happening. Despite sending shockwaves across the world, these events did not alter the course of history or prevented the Holocaust that would soon come (Figs. 1, 2 and 3).

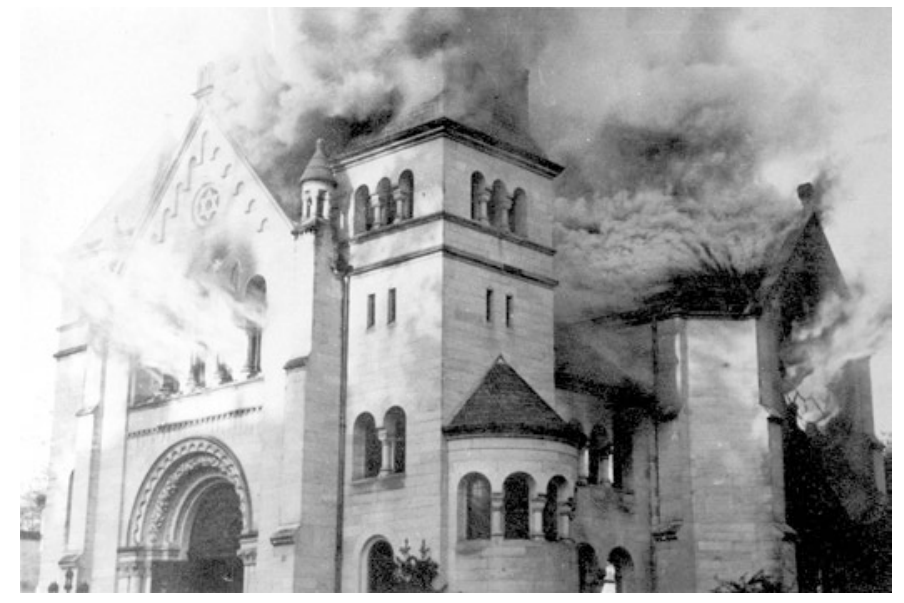

Fig. 1 Baden-Baden Synagogue on Kristallnacht, 10 November 1938. (@ Public Domain) 


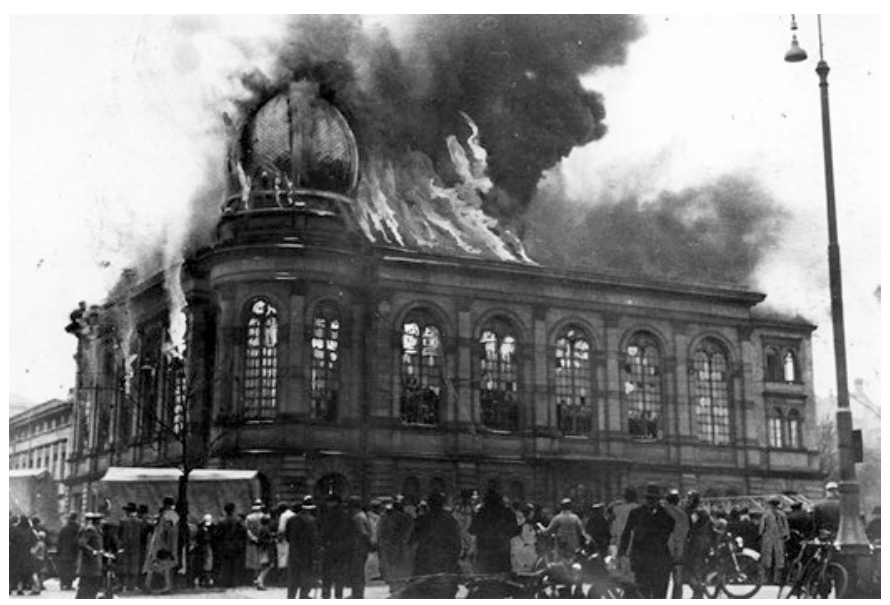

Fig. 2 Burning of the Boemestrasse Synagogue, Frankfurt on Kristallnacht, 10 November 1938. (C) Public Domain)

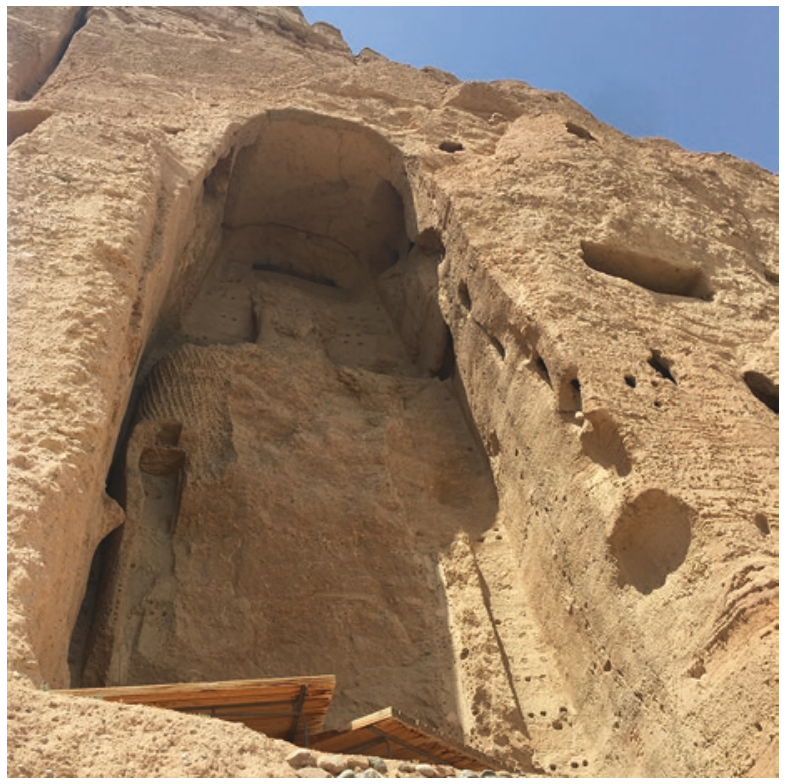

Fig. 3 Eastern Buddha niche, Empty eastern niche after the Buddha was destroyed by dynamite over several weeks, starting on 2 March 2001. (@ UNESCO/Masanori Nagaoka) 
The tragic events of the delegitimization of cultural and religious heritage have been accompanied by the violent destruction of symbolic images. This is the heading to the photographs 1-3

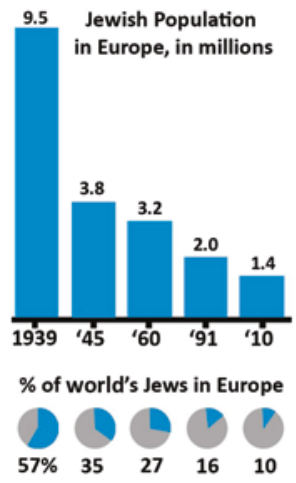

\begin{tabular}{|c|c|c|c|c|c|c|c|}
\hline \multirow[t]{2}{*}{ Year } & \multicolumn{5}{|c|}{ Number (Thousands) } & \multicolumn{2}{|c|}{ Percent } \\
\hline & Total & $\begin{array}{c}\text { West } \\
\text { Europe }\end{array}$ & $\begin{array}{c}\text { East } \\
\text { Europe, } \\
\text { Balkans }\end{array}$ & $\begin{array}{l}\text { Asia, } \\
\text { Africa }\end{array}$ & $\begin{array}{c}\text { America, } \\
\text { Oceania }\end{array}$ & $\begin{array}{c}\text { Europe } \\
\text { as } \% \\
\text { of Total }\end{array}$ & $\begin{array}{c}\text { East } \\
\text { Europe } \\
\text { as \% } \\
\text { of Europe }\end{array}$ \\
\hline 1170 & 1200 & 103 & 47 & 1050 & - & 12.5 & 31.3 \\
\hline 1300 & 1200 & 385 & 65 & 750 & - & 37.5 & 14.4 \\
\hline 1490 & 1300 & 510 & 90 & 700 & - & 46.2 & 15.0 \\
\hline 1700 & 1100 & 146 & 573 & 377 & 4 & 65.4 & 79.7 \\
\hline 1825 & 3281 & 458 & 2272 & 540 & 11 & 83.2 & 83.2 \\
\hline 1880 & 7663 & 1044 & 5727 & 630 & 262 & 88.4 & 84.6 \\
\hline 1939 & 16500 & 1350 & 8150 & 1600 & 5400 & $\mathbf{5 7 . 6}$ & 85.8 \\
\hline 1948 & 11500 & 1035 & 2665 & 2000 & 5800 & 32.2 & 72.0 \\
\hline 1995 & 13059 & 1037 & 704 & 4735 & 6583 & 13.3 & 40.4 \\
\hline
\end{tabular}

Source: 2010 estimates from the Pew Research Center's Global Religious Landscape Report. (Lipka 2015) All other years' estimates are based on the research by Prof Sergio DellaPergola of the Hebrew University of Jerusalem. (DellaPergola 2001)

The "Law for the Protection of German Blood and Honor" was passed on September 15, 1935, in Nuremberg. ${ }^{1}$ Philosopher Hannah Arendt pointed out that this was a significant judicial event of the Holocaust, and she demonstrated that to violate human rights, Nazi Germany first deprived human beings of their citizenship. Arendt underlined that in the Declaration of the Rights of Man and of the Citizen, citizens' rights actually preceded human rights, as the latter needed the protection of a state to actually be respected. The destruction of the physical heritage was a prelude to the obliteration of all human dignity and a denial of polity, which Arendt suggested finally expelled man from humanity (Arendt 1973).

Between November 20, 1945, and October 1, 1946, the subsequent trials were symbolically conducted by the Western Allies at the Nuremberg Palace of Justice, generating seminal documents and laying the foundations for the declaration on human rights, crimes against humanity, and the concept of genocide (Sands 2016).

After World War II, Europe had lost two-thirds of its Jewish population and almost all its Jewish cultural heritage. The extreme scale of the disaster became apparent in the following years as the remnants of the decimated European Jewry wandered between displaced persons camps and later global migrations, including

\footnotetext{
${ }^{1}$ The two milestone Nuremberg Laws passed in 1935 were the Law for the Protection of German Blood and German Honour, forbidding marriages and extramarital intercourse between Jews and Germans and the employment of German females under 45 in Jewish households, and the Reich Citizenship Law, determining that the eligibility for Reich citizenship was only for those of German or related blood (US Holocaust Memorial Museum 2018). The English translation is available at https://www.ushmm.org/wlc/en/article.php?ModuleId=10007903
} 
to the newly established State of Israel from 1948 onward. According to the American Jewish Year Book (Shapiro and Sapir 1950), the Jewish population of Europe was about 9.5 million in 1933, and by 1950 it had been depleted to near 3.5 million. Seven decades after the Holocaust, the number of Jews in Europe continues to decline.

Based on this perspective, Bernard Wasserstein outlines the impact on Jews on post-war reconstruction, including social and community structures, the Soviet occupation, the collapse of communism, and how this has shaped the history of European Jewry in the second half of the twentieth century (Wasserstein 1996).

Nothing remained the same. This was a definitive episode, changing the course of history. There was an urgent need to pick up the pieces, both human and physical, and reappraise the situation, and this has led to a number of significant questions.

A major factor for understanding the recovery of heritage is a deeper appreciation for the values that have been lost. What exactly was lost? The intangible human respect and moral values - the synagogues, cemeteries and ritual baths where history bears witness to knowledge and practices - and the tangible, both moveable and immovable, in the books, artifacts, and places so essential for linking to the intangible traditions and ceremonies. What remained? The physical ruins, the memory of places and events, and especially the resilience of the human spirit.

It was the horrifying reality of World War II that generated the preamble to the Constitution of UNESCO declaring that "since wars begin in the minds of men, it is in the minds of men that the defences of peace must be constructed." The purpose of the Organization has been "to contribute to peace and security by promoting collaboration among nations through education, science and culture in order to further universal respect for justice, for the rule of law and for the human rights and fundamental freedoms ...."

This highlights the significance of cultural diversity, to recognize "the other," to spread tolerance, and to reaffirm our universal responsibilities because, as the British philosopher John Stuart Mill declared: "bad men need nothing more to compass their ends, than that good men should look on and do nothing." ${ }^{2}$

\section{Jewish Texts}

The fundamental Jewish concepts take their sources from the Written and Oral Laws, with the Bible ${ }^{3}$ considered as the basic text of the Written Law. The words of God, being written by Moses as the Tora on Mount Sinai, came with an oral exegesis, handed down over generations and finally inscribed as the Mishna and the

\footnotetext{
${ }^{2}$ Littell's Living Age, 16 March 1867 [Inaugural Address at University of St. Andrews: 1 February 1867], Page 664, Number 1189, Fourth Series, Littell and Gay, Boston.

${ }^{3}$ The texts quoted from the Bible are based on the English King James Version.
} 
Tosefta, compiled from pre-200 CE memories. Subsequently, the two Talmudim (the Jerusalem Talmud, c. $450 \mathrm{CE}$ and the Babylonian Talmud, c. $600 \mathrm{CE}$ ) completed the expounding and the development of this body of knowledge known as the Oral Law.

The Midrash refers to a method of reading details into, or out of, a biblical text. Midrashic teachings, in the form of legal, homiletical, or narrative writing, were often configured as a running commentary on the Written and Oral Laws accumulated over the first millennium. They usually resolved issues of interpretation using rabbinic principles of hermeneutics and philology to align them with the religious and ethical values of religious teachers.

The second millennium CE opened with the evolution of the Kabala, together with the Aggada, the non-legalistic rabbinic literature, and the Halacha, the Jewish religious laws. In parallel with the eighteenth-century philosophers, European Jewish thought oscillated between the existentialism of Hassidism and the mainstream of the Musar, while a more secular strand developed in the form of the enlightenment of the Haskala. Each of these schools of thought produced extensive texts and tomes. The evolution of these texts and their sociopolitical contexts provide the spawning ground for the diverging attitudes to the reconstruction of cultural heritage through the ages.

\section{Some Jewish Values and Tradition}

Jewish values are embedded in the Tora. It was in the twelfth century CE that Maimonides encapsulated the thirteen principles of faith, becoming generally accepted over the centuries as the tenets of orthodox Jewry and providing an intellectual and spiritual base for debate. However, values evolve through the generations due to historical and geographic perspectives and through the accumulation of knowledge, events, and culture. We are left with a moving target and dynamic transformations when times change; people are born, migrate, and die. Places change their significances, and objects are built, adapted, modified, or destroyed, the remaining architecture being the evidence of the past. Indeed, the Burra Charter (Australia ICOMOS 2013) highlights this dilemma, noting that:

\footnotetext{
Values and beliefs (standards) are those which have significance for a cultural group or an individual, often including, but not being limited to spiritual, political, religious and moral beliefs. (Australia ICOMOS 2013, p. 20) Places may have a range of values for different individuals or groups and values are continually renegotiated.
}

If values are continually changing, how can we reconcile this with those universal values set in stone? Does this legitimize a new lease of life for cultural heritage? Three Jewish concepts are identified together with their implication on recovery and reconstructions - attitudes toward continuity, sanctity, and memory. 


\subsection{Continuity}

The continuity of life is embodied in the belief that the resurrection is one of Maimonides' thirteen principles of faith. The transformations of communities in new geo-cultural contexts have been a guiding link in the many Jewish dispersals over the millennia. In the recovery process of communities, the revitalization and the resurrection of old images are an essential element of acceptance and acquiescence.

Epistemological scenarios focus on the resurrection while relating to idyllic Edenic golden ages. Is Eden a place or time? The Tora notes that "The Lord God planted a garden eastward [as of old] in Eden, and there He put the man whom $\mathrm{He}$ had formed" - Genesis 2:8.

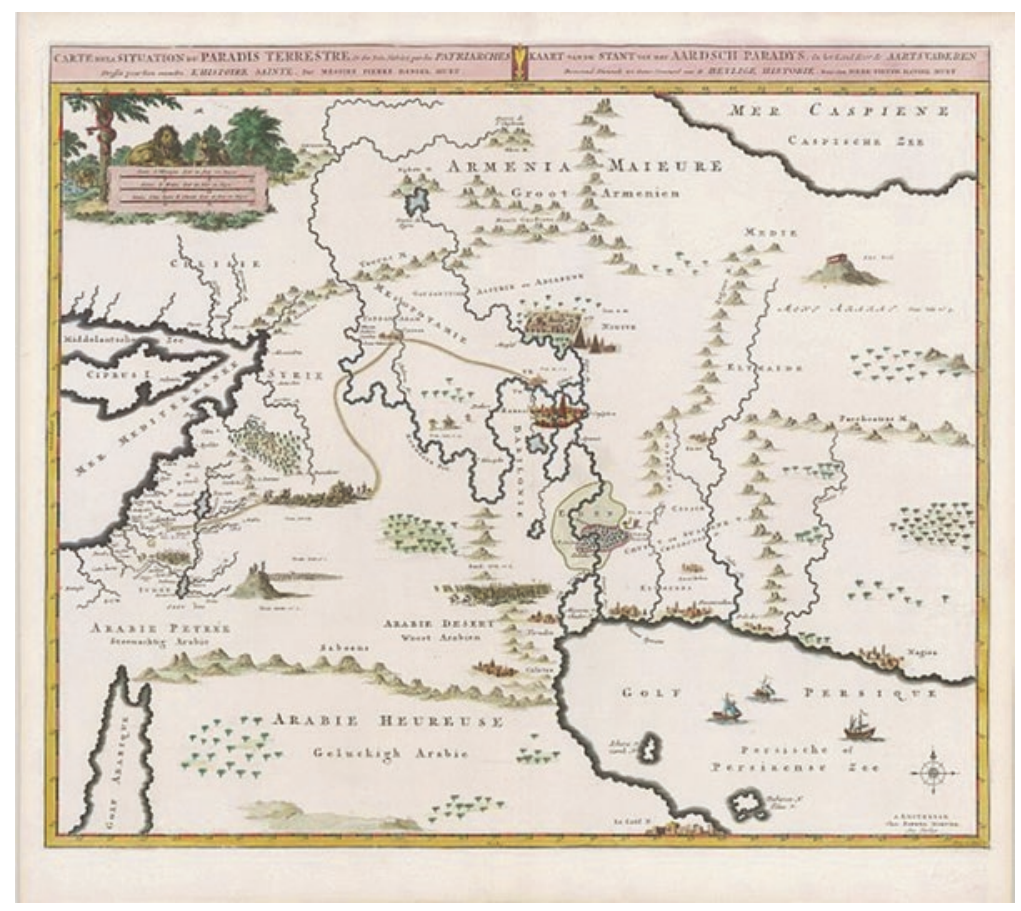

Location maps of the earthly paradise, and of the country inhabited by the patriarchs, were laid out by designers such as M. Pierre Daniel Huet and artist Pierre Mortier, for the better understanding of sacred history, especially around the seventeenth century. (@) Public Domain)

Later Biblical texts highlight the old times but continue the ambiguity between place and time, being concurrently - time, as we know it, or its idyllic counterpart. In lamenting the destruction of the first Temple, Jeremiah calls out: "Restore us to You, O Lord, that we may be restored! Renew our days as of old" Lamentations $5: 21$. This is contrasted in the wisdoms of Solomon, "Say not thou, What is the 
cause that the former days were better than these? for thou dost not enquire wisely concerning this" Ecclesiastes 7:10.

This essence of continuity has been an indispensible Jewish element for its survival through persecutions that together with the belief in the afterlife generated hope in the rebuilding of its communal institutions, both physical and functional.

\subsection{Sanctity}

The sacred is not a monolithic concept but is rather understood through three spheres of sanctity: time, people, and place. These interconnected spheres become the basis for the considerations of the hierarchy between the holy and profane and the interpretations of those cultural elements that symbolize the values of different communities of people in diverging places through the epochs of time.

- The sanctity of time

The first citation of sanctity in the Tora is on the completion of the creation of the world and the sanctification of the seventh day:

${ }^{3}$ And God blessed the seventh day, and sanctified it: because that in it he had rested from all his work which God created and made. (1 Moses, Genesis 2)

Abraham Joshua Heschel underscores that the Bible gives importance to history rather than geography (Heschel 1983). The agricultural festivals linked to the seasons celebrated the life of nature. However, with the dispersals and migrations of the Jewish people, the transformation of these festivals into the commemoration of events was a significant change. Holiness in time was now firmly attached to a sacred event and constituted a tradition merging people and place, celebrated weekly. There was little room for the physical trappings. Subsequently, the unique historical events became spiritually more important than the cycles of nature. Heschel then focused on the Sabbath as the great cathedral of time and the Holy of Holies, termed the Sabbath of Sabbaths, as a shrine that neither the Romans nor the Nazi regime "were able to burn; a shrine that even apostasy cannot easily obliterate: the Day of Atonement" (Heschel 1983, p. 8).

- The sanctity of people

People are sanctified through their good deeds, and these are manifested in their journeys and pilgrimages; the traditions and ceremonies, events and occasions. It is in the preparation for the receiving of the Decalogue that we find the second sphere of sanctification in the Tora:

\footnotetext{
${ }^{10}$ And the LORD said unto Moses, Go unto the people, and sanctify them today and tomorrow, and let them wash their clothes, ${ }^{11}$ And be ready against the third day: for the third day the LORD will come down in the sight of all the people upon Mount Sinai. ${ }^{12}$ And thou shalt set bounds unto the people round about .... (2 Moses, Exodus, 19)
}

Yet again, the focus is on the intangible and the marking of time being the third day and the creation of a physical boundary, a temenos. 


\title{
- The sanctity of place
}

The third sequential sanctification is place. Time was hallowed by God; space, the Tabernacle, was consecrated by Moses (Heschel 1983, p. 10). Place is a cultural construct consecrated by the intangible - the ceremonies and traditions - whereby people sanctity place.

${ }^{24} \ldots$ in all places where I record my name I will come unto thee, and I will bless thee. 2 Moses/Exodus 20

Judaism is restrictive in its identification of holy places, and the concept of 'seizing the horns of the altar', where place sanctifies people, was not considered positively.

The prevention of the deification of place is inherent in the text that God had "... buried him [Moses] in a valley in the land of Moab, over against Bethpeor; but no man knoweth of his sepulchre unto this day" Deuteronomy 34:6. One can but imagine the hullabaloo around the resting place of Moses if this was commemorated.

Sanctity of place was attributed to places of worship, with the pinnacle of the hierarchy being the Holy of Holies, in the Temple at Jerusalem. However, with Jewish migrations, it became necessary to address the issues of change and the desanctification of place. Can one de-sanctify a synagogue? Is the value in the material or the use? The synagogue took on spiritual significance after the destruction of the Second Temple in $70 \mathrm{CE}$ so that the Mishna elucidates the sale of a synagogue:

\begin{abstract}
If the townspeople sell the village square [an area that retains some holiness as people use the square to pray during fasts] they must use the proceeds to purchase a synagogue. If they sell a [village] synagogue they purchase with the proceeds an ark [a city synagogue may not be sold since it was built with the intention that travellers would use it; hence it belongs to the general public]. If they sell an ark they purchase with the proceeds Torah covers. If they sell Torah covers they purchase with the proceeds scrolls of Scripture. If they sell scrolls of Scripture they purchase with the proceeds a Torah scroll [the concept being that the proceeds of a sale may only be used to purchase something with a higher degree of holiness].

(Machon Yisrael Trust 2012) ... Mishna, Megillah 3: $a^{4}$
\end{abstract}

While there are other minutiae, the basic concept is that the proceeds of a sale may only be used to purchase something with a higher degree of holiness. The range of holiness goes from the immoveable to the moveable, from the city square via the synagogue and ark to the Tora scroll and the knowledge that one keeps - the quintessence being that one should always elevate his or her sanctity. Community property is not sold to an individual since this lowers the degree of holiness. Nevertheless, a central city synagogue may not be sold because it was also built with the purpose of being used by travelers, thus putting it in the public realm.

Referencing these values in the material or the use is a guiding principle for the debate on the reconstructions of the cultural heritage, the transference of the holy, and the understanding of impermanence.

\footnotetext{
${ }^{4}$ This English text from the New Integrated Translation and Commentary is reproduced with permission of the publisher.
} 


\subsection{Memory}

Jewish identity has been shaped by collective memory throughout the ages, representing a synthesis of history and peoplehood. Halbwachs introduced the notion of collective memory as transmitted through the institutions of the group (Halbwachs 1992). For the Jewish people, collective memory flows through events, ritual, and recital. Building on the Midrash, Rabbi Schneur Zalman of Liadi, the founder of Chabad, a branch of Hasidic Judaism at the turn of the eighteenth century, codified six such events from the Tora into his Six Remembrances, one being the Sabbath. The two Tora Decalogue texts refer to the sanctity of the Sabbath, in Exodus "remember the Sabbath" while in Deuteronomy "observe the Sabbath." Midrashic explanation reconciles this disparity with the merging of the two words and by justifying that sanctification is simultaneously achieved through memory and observance.

Memory can also be recalled through the associations of the physical attributes of the events. The memory of WWII is tied up in the understanding of the memory of loss - remembering the loss through contemplating the ruins or the empathy of the suffering in the concentration camps. Does time heal? Let us take a possible Judaic approach, the 49-year cycle in Judaism as a release of the soul, when the personal memory transposes itself into the collective memory - it is the representation of the generation change and a time for "release" from the bonds of memory. Being an important function, the memory of the events needs time and place to understand their perspective, moving from the individual to the collective memory.

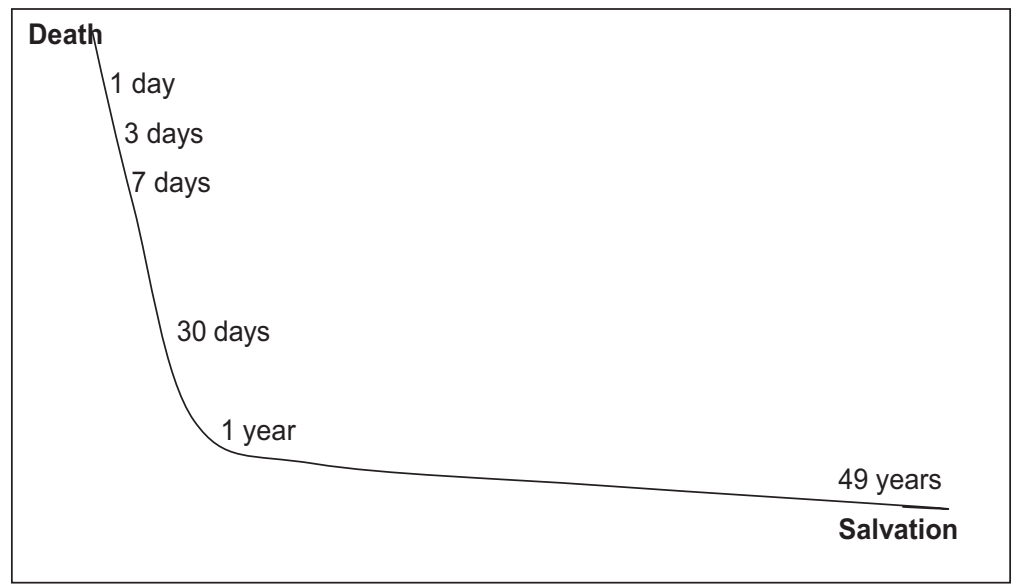

From the personal to the collective memory

From the personal to the collective memory - Jewish ceremonials to the memory of the dead and mourning between the first and the forty-ninth year. The first day wake, before burial, 3 days of crying; the 7, Shiva, and 30, Shloshim, days of mourning; the year of the Kaddish, with the subsequent Yahrzeit and annual reciting of the Kaddish; and finally, according to some Hassidic sources, a ceremony on the completion of seven cycles of seven; after this time with a new generation, the individual memory of this person is lost or may continue in the collective memory of the descendants - drawing by the author 


\section{Interpretations}

What values may be reinstated and how can they be interpreted? Values based on the past that no longer exist; the tragic events of the present; or the new realities of the future? The lessons of the events create new and changing values, often conflicting and requiring compromise and negotiations.

It all comes down to interpretation. Such interpretations have evolved over the centuries and were tempered by time and geo-political considerations. While there might be an agreement as to the values and the articles of faith, the bones of contention are in the elucidation of these texts. Here, existential or historical models play a major role, together with intra-religious tensions: Hassidic Judaism leaning towards the former and nationalistic Judaism toward the latter. The intangible and the beliefs, in the form of traditions and ceremonies, have currently been subordinated to the fundamentals of historical reality.

The study of language through structural linguistics was developed by Charles Bally and Albert Sechehaye on the basis of the lectures of Ferdinand de Saussure between 1906 and 1911. This analogy to heritage can be understood through the debate on synchronic and diachronic linguistics, adapted from two different and complementary viewpoints, whereby the synchronic approach considers a language at a moment in time without taking its history into account. By contrast, the diachronic approach considers the development and evolution of a language through history (De Saussure 1959), the functional continuity of the diachronic in contrast to the synchronic adaptive re-use for the needs of the present.

Reintegrating the traces of Jewish Heritage in the diachronic urban fabric might benefit from the 2011 UNESCO Recommendation on the Historic Urban Landscape (HUL), which "defines the historic urban landscape as the urban area understood as the result of a historic layering of cultural and natural values and attributes, extending beyond the notion of 'historic centre' or 'ensemble' to include the broader urban context and its geographical setting" (UNESCO 2011).

In the Tora, at the end of the Book of Deuteronomy, there is a description of the last days of the desert generation and consoling the leaders. The Midrash expresses the adage: "God had said to Moses, that is the way of the world, each generation and its interpreters, each generation and its supporters and each generation and its leaders" Midrash Tanhuma. ${ }^{5}$ This represents a more synchronic approach whereby reconstruction is pushed aside, and contemporary ideas become acceptable.

\footnotetext{
${ }^{5}$ Midrash Tanhuma, a comprehensive name for three collections of Agada, being the non-legalistic exegetical texts of the Tora including homiletical narratives and stories.
} 


\section{Reconstructions}

In this synchronic mode, once the synagogue has been sold or destroyed, its reconstruction may be an issue ab origine. There is little need to reconstruct the architecture, and there is little meaning in the urban context without the Jewish life. Cyrus II, king of Persia, issued the Directive to the Jews to rebuild the Temple and allow the return of the exiles to Jerusalem in 538 BCE. The Book of Ezra recalls the dedication of the rebuilding of the Temple in $516 \mathrm{BCE}$ and the diverging opinions as to its reconstruction:

${ }^{12}$ But many of the priests and Levites and chief of the fathers, who were ancient men, that had seen the first house, when the foundation of this house was laid before their eyes, wept with a loud voice; and many shouted aloud for joy:

${ }^{13}$ So that the people could not discern the noise of the shout of joy from the noise of the weeping of the people: for the people shouted with a loud shout, and the noise was heard afar off. (Ezra 3: 12-13)

Where Jewish life no longer exists, there can be no spirit of place. With dwindling numbers of Jews, even if the physical fabric remained, it is unlikely that the current historic uses are relevant. In 1944, Hannah Arendt was appointed as the director of research for the Commission on European Jewish Cultural Reconstruction (Arendt 1950). She visited Germany and submitted reports on the state of conservation of Jewish heritage (which provide an insight to her writings, some 30 years later), noting that " $[\mathrm{t}]$ he cultural treasures of the past, believed to be dead, are being made to speak, in the course of which it turns out that they propose things altogether different than what had been thought" (Arendt 1978, p. 294).

\subsection{Marking the Events}

The reconstruction may also relate to marking the events of destruction, recording the loss, or celebrating the cultural heritage of the past and its renewal.

Was the destruction and massacre itself an event of Outstanding Universal Value? In considering the events of World War II vis-à-vis the World Heritage criteria (UNESCO 2016), we might suggest in evaluating the vestiges of the Jewish cultural heritage that:

- the site becomes an "exceptional testimony to a cultural tradition or to a civilization which ... has disappeared" (iii)

- It represents "an outstanding example of a traditional human settlement... which is representative of cultures or human interaction with the environment especially when it has become vulnerable under the impact of irreversible change" (v)

- It is "directly or tangibly associated with events .....of outstanding universal significance" (vi)

But which values are reflected in the event? The first group of values represents the historic events of Holocaust, crimes against humanity, genocide, and 
anti-Semitism, while the second group relates to the lessons learned including tolerance, democracy and human rights, war and peace, and silence. The attributes of these, often contentious, values are diverse, and their manifestations may stand in contrast with other values of Jewish heritage.

\subsection{The Continuity and Impermanence of Jewish Cultural Heritage}

The specific physical Judaic attributes that are site-specific might include evidence of the architecture: the synagogues and the shtieblech/prayer houses, the Mikveh/ ritual bath, the Houses of Learning/Bet Midrash, and Talmud Torah. The urban attributes may consist of the ritual enclosures/eruv, ${ }^{6}$ the courtyards, the Jewish districts/ ghettos, and their relationships to the city, the cemetery, and other public spaces, including the place for the announcements of "lost and found."
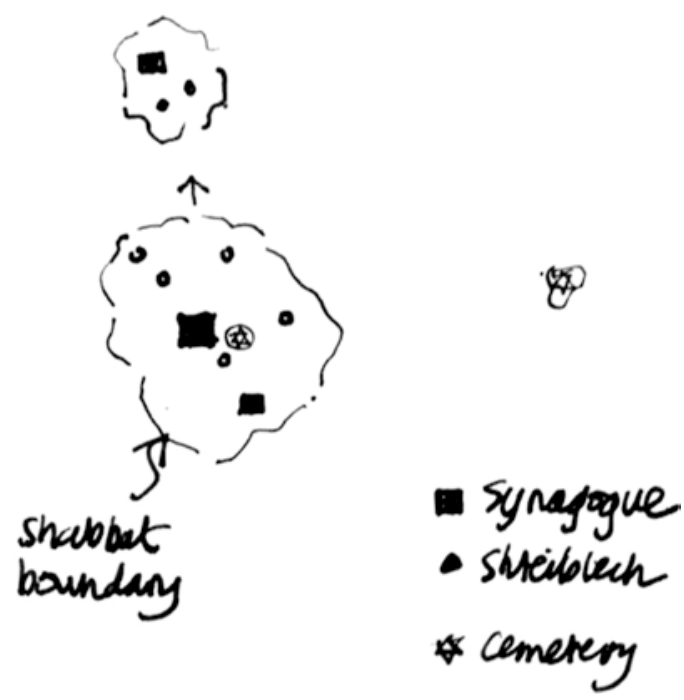

Figure: The individual elements of Jewish life as the synagogue, the shtieblech, ${ }^{7}$ and the cemetery are contextualized including the urban references and Sabbath boundaries. Over time, new Jewish communities are established with their burial places consecrated outside the city limits. Source: author

\footnotetext{
${ }^{6} \mathrm{An}$ urban area enclosed by a wire boundary that symbolically extends and integrates the private domain of Jewish households into public areas, permitting activities within it that are normally forbidden in public on the Sabbath.

${ }^{7}$ Shtieblech is Yiddish for a small house and refers to rooms of prayer and study, often improvised and usually in the Hassidic tradition.
} 
The World Heritage Convention is a site-based convention not associated with moveable objects ${ }^{8}$ (UNESCO 2016). The residual tangible assets, the remnants of history, have been deemed by Francis Bacon in his 1605 definitions of history as the "shipwrecks of time" (Bacon 1877), thereby becoming the pivot point for discussion. What can we recognize from these "shipwrecks," which values do they represent, and for whom can we understand the narrative of the past? Furthermore, the existing attributes of each of the values will determine the format of the conservation policies and, more so in these circumstances, through a process that might be called "reverse evaluation." This entails recognizing the physical attributes that have survived and then identifying the values that can possibly be recalled and associated with these attributes.

These shipwrecks of time, the ghosts of the past in the tangible remnants of the synagogues, mikvaot, and cemeteries, represent the inanimate scars of history and are now being evaluated and differentiated from the intangible, embodied in the sites of conscience and sites of memory. ${ }^{9}$

\section{The Case Study of ShUM}

The case study of the ShUM cities in Germany, including Speyer, Worms, and Mainz (Preissler 2012), provides a glimpse into the debate and an appraisal of this moment in time. Each of these three cities represents a diverging methodological approach - the archaeological ruins of Speyer, the reconstruction at Worms, and the renewal of Mainz.

In her Jewish Spaces, German Obligation, World Heritage? (Urban 2016), Susanne Urban wrote that for decades there was a deracinated wholeness of Jewish space and landscape around the synagogues and mikvaot, primarily presented as a historical and ethnographic space, administered by cities, tourism offices, archives, and other professional institutions. She argues that "we cannot help but recognize that Jewish history in Germany is founded on a thousand-year-old-tradition. That is all well and good. But the narratives fashioned for tourists and other visitors often reflect a skewed perception of history. ShUM is distant. The descriptions of the Crusades from the eleventh century or the pogroms in the fourteenth century seem far away in space and time; their horrors are overshadowed by the Shoah" (Urban 2016).

\footnotetext{
${ }^{8}$ Paragraph 48 of The Operational Guidelines for the Implementation of the World Heritage Convention

Movable Heritage 48. Nominations of immovable heritage which are likely to become movable will not be considered.

${ }^{9}$ The World Heritage Committee at its 42 session was presented with a report on Sites of Memory as Guidance and Capacity Building for the Recognition of Associative Values Using World Heritage Criterion (vi), Final Report, January 2018 (by Prof. Christina Cameron and Judith Herrmann, University of Montreal, Canada), and Interpretation of Sites of Memory prepared by the International Coalition of Sites of Conscience (Washington, USA), led by Jean Louis Luxen with the support of Christopher Young, together with a working group. Final Report 31 January 2018.
} 
There are some critical issues that need to be faced in the ShUM nomination. How are these cities understood for Judaism and Jews worldwide - and what do they mean to non-Jews? Urban notes that there is a self-referential "Vergangenheitsbewältigung," or "coming to terms with the past," without much contact or connection to the living Jewish present. The cities connect Jewish with European and global history, illustrating the interconnections between cultures and beliefs. The history of these cities over a millennium may signify coexistence and interaction, together and side-by-side, with periods of flourishing and decline, expulsion, and murder.
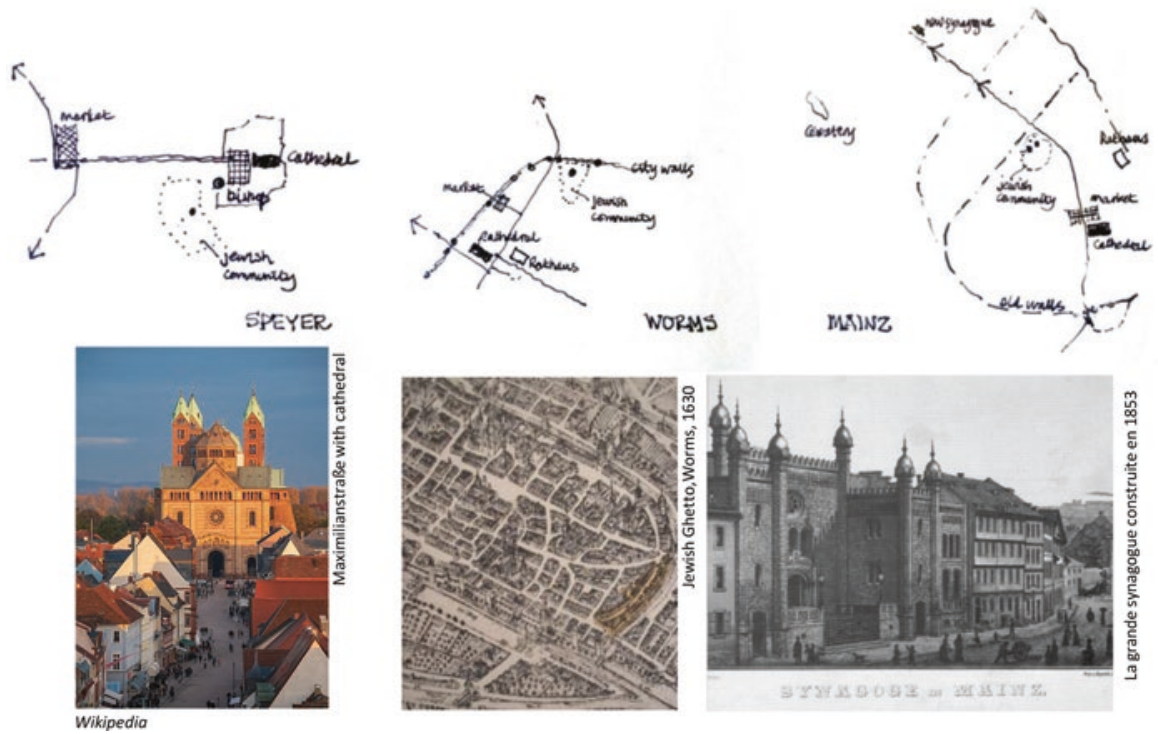

Figure: The urban context of the historic Jewish Quarters in Speyer, Worms, and Mainz and their relationships to civil and religious foci. The Jewish Quarters in Speyer and Mainz are under the patronage of the Church and local Bishops, while in Worms the Jewish Quarter developed in peripheral areas by the city walls. (@ Roman Eisele / Wikimedia Commons / CC BY-SA 4.0) (C) Public Domain - https://commons.wikimedia.org/wiki/File:Worms_1630_P7160060.JPG) (@ Public Domain - https://fr.wikipedia.org/wiki/Grande_synagogue_de_Mayence_(1912-1938)\#/ media/Fichier:Hauptsynagogue_in_Mainz_-_1853.jpg)

\subsection{Speyer: Archaeological Ruin}

In the context of Walter Benjamin's philosophy of history, the ruin provides an emblem, not only of the melancholic world view presented in the Baroque tragic drama but of the allegory as a critical tool for historical materialism (Benjamin 2009). Benjamin's concept of the ruin, especially as sketched in his book The Origin of German Tragic Drama, is valuable because it delves beyond the aesthetic of the ruin as an object, reading it as a process, a means of stripping away symbolism - a means of approaching historical truth through reduction, at the expense of romantic aesthetics: 


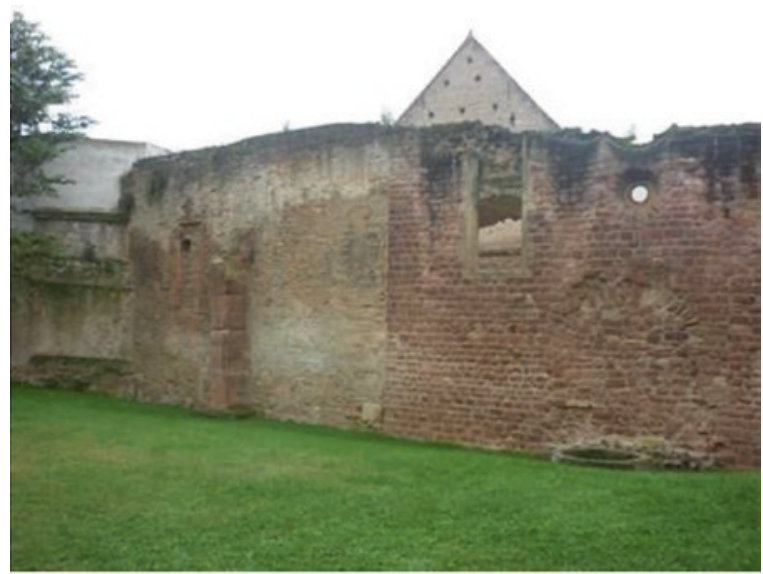

Speyer - archaeological ruin in the Judenhof

In the ruin, history has physically merged into the setting. And in this guise, history does not assume the form of the process of an eternal life so much as that of irresistible decay. Allegory, therefore declares itself to be beyond beauty. Allegories are, in the realm of thoughts, what ruins are in the real of things. (Benjamin 2009, pp. 177-178)

The legacy of Speyer is represented in the architectural ruin and its urban context in the shadow of the Cathedral and by the Bishop's Residence.

\subsection{Worms: Reconstruction}

The reconstruction of the Worms' synagogue using much of the original material was the initiative of the former director of the city archives and museum in Worms, Dr. Friedrich Illert, with the support of Isidor Kiefer, the director of the prewar Jewish museum. This action must also be recognized as Reconstruction for Reconciliation. The synagogue, open as a museum, continues to be a functioning synagogue used intermittently by the small Jewish community (Roemer 2010). While the attributes of the chronological value of the ShUM World Heritage nomination are in the medieval foundations, the value of "continuity" highlights the possible attributes of the changing uses and design over the period of life of the community. In both cases, the reconstruction narrative seems logical.

It should be noted, however, that most of the survivors outside Germany were of the opinion that the reconstruction would represent an antithesis to the situation as the event should be recognized because nothing was the same again after the Shoah (Urban 2017). This brings us to the Nara Document (UNESCO, ICOMOS, ICCROM 1994) and the dissonant responsibilities of the communities, those that created the heritage in the past and those managing this heritage in the present. 


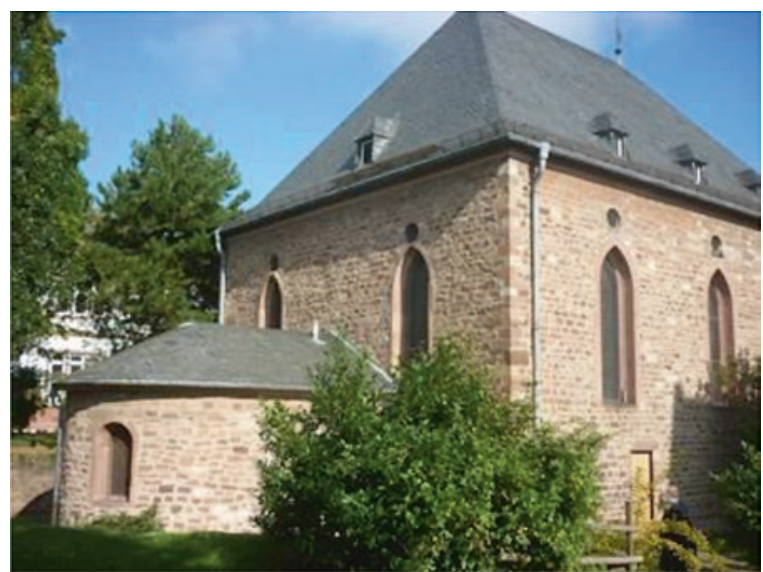

Worms - reconstruction of the Alte Synagogue

\subsection{Mainz: Renewal}

The long and turbulent history of the Jewish community in Mainz is indeed a microcosm of European Jewry, oscillating between acceptance and rejection, from the end of the ninth century till World War II. Although it was not a large community, it played an important role with the authority of the religious leaders acknowledged in Europe, through the assemblies that were held in Mainz in the twelfth and thirteenth centuries. The massacres as a result of the Crusades, the Black Plague, the seventeenth-century French occupation, and, finally, the Nazi regime, regularly decimated the community. In the intervening years, however, the Mainz Jewish community flourished together with its local rulers, and it is this continuity that is celebrated. Some $80 \%$ of Mainz was bombed and destroyed in WWII, and little remains but the commemorative Jewish cemetery and the hope that comes with the new deconstructivist synagogue.

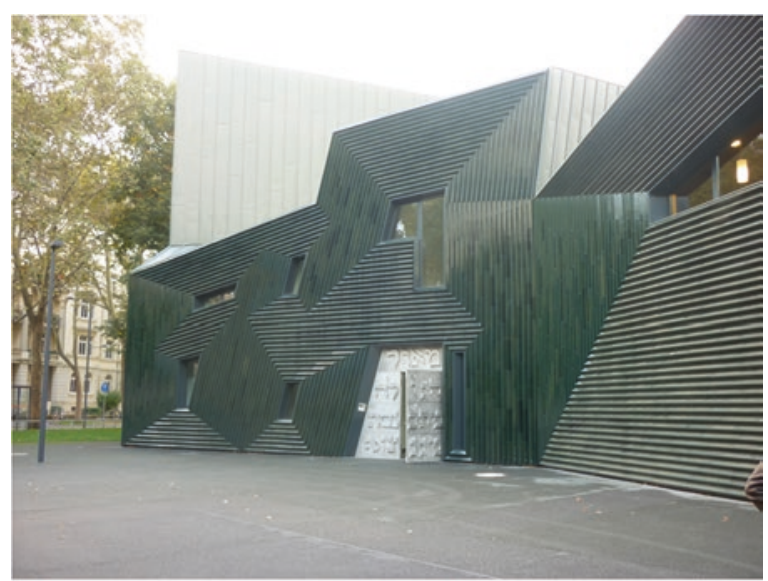

Mainz - renewal by architect Manuel Herz 


\section{Discussion: Parallels and Conclusions}

There is no single Jewish formula for reconstruction. The values may be eternal but the interpretations are varied and vibrant. However, I believe that the more existential approach and the focus away from the tangible to the intangible should hold sway. The effects of two millennia of Diaspora have highlighted the need to be responsive and reactive to developing circumstances and outright anti-Semitism. Judaism leaves room for the "other," real and virtual, past, present, and future, with an approach that values the minimum necessary and the maximum possible to ensure that all narratives are being heard. Farmers were instructed in the Tora to leave unharvested corners for the poor and needy together with portions of leftover sheaves in the field.

The Nara Document (UNESCO, ICOMOS, ICCROM 1994) focuses on cultural diversity and heritage diversity, linking two major communities and within which there are a multitude of subgroups, especially in the world of global virtual reality:

8. It is important to underline a fundamental principle of UNESCO, to the effect that the cultural heritage of each is the cultural heritage of all. Responsibility for cultural heritage and the management of it belongs, in the first place, to the cultural community that has generated it, and subsequently to that which cares for it. ...Balancing their own requirements with those of other cultural communities is, for each community, highly desirable, provided achieving this balance does not undermine their fundamental cultural values. (UNESCO, ICOMOS, ICCROM 1994, p. 1)

Who might be considered "the cultural community that generated [this heritage], and subsequently to that which cares for it"? The descendants of the last residents or perhaps a virtual community of those empathizing with the past may also claim a stake in the debate. Cultural communities, both real and virtual, may similarly play a vital role in generating new narratives and objectively recognize the lessons learned or the need for cultural diversity, tolerance, and the recognition of the "other." In ever-changing communities and cities, many of the traditional activities no longer exist and all the more so in Jewish Europe or the Buddhist Bamiyan Valley.

These reconstructions for an uprooted community are paralleled with the cultural landscape of the Bamiyan Buddahs. The original communities and their descendants are no longer present. These are spaces from the past that have no use in the present, except as a possible narrative for the future and as a word of warning to ourselves and the world as to the dangers of racism. The values remaining are in their inanimate architectural and physical attributes and the meanings of their destruction. While celebrating continuity, both Judaism and Buddhism embrace degrees of impermanence often generating ambivalent attitudes to reconstruction.

Facing the dislocated communities reduces the vestiges of the past and the ruins with their scars of history as evidence of the place; John Ruskin in the Lamp of Memory addressed these very issues in preferring "the rudest work that tells a story or records a fact," as opposed to "the richest without meaning"; more has been gleaned out of desolated Nineveh than ever will be out of re-built Milan (Ruskin 1889, p. 196). 
As to the reconstructions of Jewish synagogues, we are left with a new physical object, while the complexities of the reconstructions of the Bamiyan Buddahs are compounded with the rock-cut works of centuries. Ruskin would determine in both cases that:

...; it is impossible, as impossible as to raise the dead, to restore anything that has ever been great or beautiful in architecture. .... that spirit which is given only by the hand and eye of the workman, can never be recalled. Another spirit may be given by another time, and it is then a new building; but the spirit of the dead workman cannot be summoned up, and commanded to direct other hands, and other thoughts. (Ruskin 1889, p. 194)

Perhaps a more spiritual meaning is needed; therefore, the dilemma is not whether to reconstruct or not, or any variants, but to remember or to forget, to celebrate, or to mourn, in retribution or forgiveness.

\section{References}

Arendt, H. (1950). Jewish cultural reconstruction field reports, 1948-1951; field report no. 18, February 15 - March 10 1950. Hamburg: Leo Baeck Institute.

Arendt, H. (1973). The Origins of Totalitarianism. Orlando: Houghton Mifflin Harcourt.

Arendt, H. (1978). Politics and philosophy of history: Martin Heidegger at eighty. In M. Murray (Ed.), Heidegger and modern philosophy: Critical essays. New Haven: Yale University Press.

Australia ICOMOS. (2013). The Burra charter - The Australia ICOMOS charter for places of cultural significance. Burwood: Australia ICOMOS.

Bacon, F. (1877). The works of Lord Bacon, moral and historical. London: Ward, Lock and Company.

Benjamin, W. (2009). The origin of German tragic Drama. Croydon: Verso.

De Saussure, F. (1959). Course in general linguistics (3rd ed.). New York: The Philosophical Library, Inc.

DellaPergola, S. (2001). Some fundamentals of Jewish demographic history. In S. DellaPergola \& J. Even (Eds.), Papers in Jewish demography (Vol. 1997, pp. 11-33). Jerusalem: The Hebrew University.

Gilbert, M. (2006). Kristallnacht: Prelude to destruction (1st ed.). New York: HarperCollins.

Halbwachs, M. (1992). On collective memory. Chicago: University of Chicago Press.

Heschel, A. J. (1983). The Sabbath - its meaning for modern man (8th ed.). New York: Farrar, Straus and Giroux.

Lipka, M. (2015). The continuing decline of Europe's Jewish population. Washington, DC: Pew Research Center.

Machon Yisrael Trust. (2012). The Mishnah: A new integrated translation and commentary. Lakewood: Israel Bookshop Publications.

Preissler, M. (2012). The Shum cities of the Rhine. Mainz: Directorate-General of the Cultural Heritage of Rhineland-Palatinate.

Roemer, N. (2010). German City, Jewish memory: The story of Worms. Waltham: University Press of New England.

Ruskin, J. (1889). The seven lamps of architecture (6th ed.). Orpington: George Allen.

Sands, P. (2016). East West Street - On the origins of genocide and crimes against humanity (1st ed.). London: Weidenfeld \& Nicolson.

Shapiro, L., \& Sapir, B. (1950). World Jewish population (11th ed.). Philadelphia: Jewish Publication Society and the American Jewish Committee.

UNESCO. (2011). Recommendation on the historic Urban landscape. Paris: UNESCO. 
UNESCO. (2016). Operational guidelines for the implementation of the world heritage convention. Paris: UNESCO.

UNESCO, ICOMOS, ICCROM. (1994). Nara document on authenticity. Paris: UNESCO, World Heritage Committee.

Urban, S. (2016). Jewish Heritage Europe. [Online] Available at: http://jewish-heritage-europe. eu/have-your-say/jewish-spaces-german-obligation-world-heritage. Accessed 26th July 2018.

Urban, S. (2017). The ShUM cities today: Symbolic topography or Jewish spaces? Jerusalem: World Union of Jewish Studies.

US Holocaust Memorial Museum. (2018). Holocaust Encyclopedia. [Online]. Available at: https:// www.ushmm.org/wlc/en/article.php?ModuleId=10007903. Accessed 26 July 2018.

Wasserstein, B. (1996). Vanishing diaspora: The Jews in Europe since 1945. Cambridge, MA: Harvard University Press.

The opinions expressed in this chapter are those of the author(s) and do not necessarily reflect the views of the UNESCO, its Board of Directors, or the countries they represent.

Open Access This chapter is licensed under the terms of the Creative Commons AttributionShareAlike 3.0 IGO License (https://creativecommons.org/licenses/by-sa/3.0/igo/), which permits use, sharing, adaptation, distribution, and reproduction in any medium or format, as long as you give appropriate credit to UNESCO, provide a link to the Creative Commons licence and indicate if changes were made. If you remix, transform, or build upon this chapter or a part thereof, you must distribute your contributions under the same licence as the original. This publication is also available at the UNESCO Open Access Repository: https://unesdoc.unesco.org/

The designations employed and the presentation of material throughout this publication do not imply the expression of any opinion whatsoever on the part of UNESCO concerning the legal status of any country, territory, city or area or of its authorities, or the delimitation of its frontiers or boundaries.

The authors are responsible for the choice and the presentation of the facts contained in this chapter and for the opinions expressed therein, which are not necessarily those of UNESCO and do not commit the Organization. 